\title{
An Appraisal of Copyright Administration in Nigeria towards a Sustaible Development
}

\author{
Bunu Mallam Abubakar*, Mohammad Amin Umar**, \\ Mohammed Alhaji Audu*** \\ * Faculty of Law, Department of Private Law, University of Maiduguri Nigeria \\ ** Faculty of Law, Department of Private Law, University of Maiduguri Nigeria \\ ***Faculty of Management Sciences, Department of Finance, University of Maiduguri Nigeria
}

\begin{abstract}
Until December $24^{\text {th }} 1970$ when the Nigerian Copyright Act came into operation, the Nigerian copyright is being governed by the English Copyright Act of 1911 which was made applicable to Nigeria by virtue of an order-in-council No.912 of June 24, 1912. The shortcoming of the 1970 Act gave birth to the copyright Act 1988 which was further amended in 1992 and 1999. However, the copyright Act CAP C28 laws of Federation of Nigeria 2004 is the current legislation which establishes a commendable institutional framework and foremost agent in the fight against piracy and for the enthronement of effective and efficient copy right legal regime. The discourse within the purview of this paper is to dissect legal provisions that empower this institutional infrastructure with a view to understanding its prospects and challenges and the possible area of reforms.
\end{abstract}

\section{Introduction:}

The primary aim at discovering the developments of the legal protection which is assigned to the creative and artistic work are under the name and style of copyright administration in Nigeria. The annual copyright forum was instituted as one of the vital organs for the administration of copyright in the country. In fact the administration of

Copyright protection must be carried out within an existing legal framework. Generally, the term copyright law is a branch of that part of law which deals with the rights of intellectuals creators and such rights are respected by the laws of most countries Nigeria inclusive. The reasons for this respect of the rights of creators are the needs to stimulate and foster the creativity of men and women in the society. ${ }^{1}$

The word copyright is a species of intellectual property with its own unique character. ${ }^{2}$ First it is a property right that at the same time exhibits features of a personal right. Rationalizing the classification of copyright as property Erie, J. had argued in JEFFREYS BOOSEY. ${ }^{3}$

"It is true that property in the order of words is a mental abstraction, but so also are many other kinds of property. For instance, the property in a stream of water which is not in any of the atoms of the water, but in the flow of the stream. The right to stream none the less a right of property, either because generally belongs to the proprietor, or because the remedy for a violation of the right is by action in the case, instead of the detinue or troves."

In essence, if the person who makes physical objects through manual labour and craft is readily granted property right in his product, then there is a moral persuasion why another should be allowed to enjoy similar treatment and obtain proprietary rights over the products of his mind.

The cornerstone of a copyright system is a well established and widely respected copyright organization which under takes safeguarding of the rights and interests of authors, the collection and distribution of their royalties and which can distribute also to the promotion of education and culture, as well as on the participation in international cultural exchange. ${ }^{4}$ Therefore, collective administration through such organization is now widely applied, it is even more important than before that it be really correct administration of rights rather than a disguised form of compulsory licensing or a sort of collective rights. This was clearly brought out during the world international property or organization (WIPO) and international forum on collective administration of copyrights and neighboring rights which was held in Geneva from May $12^{\text {th }}-14^{\text {th }} 1986$, which allowed a very useful exchange of information and views with the frame work of the berne convention particularly between the representative of government intergovernmental and nongovernmental organizations. Among the participants, were leading federations and other organization representing authors, performers,

\footnotetext{
${ }^{1}$ E.E. Uvieghara "copyright Law and administration (1992)" P.1 Published by Y. Books

${ }^{2}$ J.O. Abein "Nigerian copyright law and practice (2003) P.5 published by Nigerian copyright commission Abuja First Edition

${ }^{3}(1885)^{4}$ H.L.C. P.815

${ }^{4}$ Ibid
} 
publishers, film makers television and radio broadcasters and phonogram producers. Therefore, due to the above, the WIPO continue to pay particular attention to rendering assistance to the developing countries establishing and modernizing copyright legislation and the administrative structure.

Until 1988 when the copyright act was passed into law, there was no effective administrative infrastructure for copyright practice in Nigeria. The act, ${ }^{5}$ provides for the establishment of a body to be known as the Nigerian copyright commission.

\section{The Basic Term Of The Defination Of Copyright}

The copyright act does not provide a definite meaning of the word "copyright" within the provision of the act unless the context otherwise admits, reference to the copyright act as amended by the copyright (amendment) decree no.98 of 1992 and by the copyright (amendment) decree no.42 of 1992 respectively. ${ }^{6}$ It further suggested that copyright protection in Nigeria can only derive from the provisions of the act and, by implication that no copyright claim exist outside the statute or laid no definition to the subject matter. ${ }^{7}$ Elias, in his book, defines the term copyright as the right of author, to prevent others from publishing or reproducing his work without the owners prior consent. ${ }^{8}$ Obatosin Ogunkoye defines it as;

"copyright, simply put it as exclusive right given under the law to the owner of copyright to control the reproduction of the copyright of work which is subject of copyright". ${ }^{9}$

The above two cited definitions are common phenomena running through the definitions and which is the exclusive right of the copyright owner. The right so conferred on the copyright owner is exercisable by him alone or another person with his consent. ${ }^{10}$ Copyright in Nigeria is a statutorily granted right exercisable by certain group of persons, ${ }^{11}$ over some designated works of art, ${ }^{12}$ and upon specified terms and condition as provided by the law. ${ }^{13}$ to a layman, copyright may seem to be the right for him to copy as known to law, is a negative right and it is not a right to do anything but rather to stop others from doing something.

Copyright has also been defined as exclusive legal right, held for certain number of years to print, publish, sell, broadcaster, perform, film or record an original work or any part of but the above definition gives the wrong notion that the only qualification required of a work to be protected by a copyright is originality. ${ }^{14}$

One other definition stated that, copyright is the exclusive right of the owners of certain works which qualify for protection under copyright to produce, communicate to the public or broadcast, adapt or translate the whole work or substantial part of the work either in its original form or in any other form recognizably derivable from the original. ${ }^{15}$

According to another write, copyright is simply the exclusive right to control the doing in Nigeria of certain acts in relation to the work in which the right subsists. ${ }^{16}$

It is clear that, going by the above two definitions the authors failed to consider the exception laid, down by the act which denied the owner of a copyright the word "exclusive and absolute right" in the totality. ${ }^{17}$

\section{The Orgnizational Structure Of Copy Right Administration In Nigeria}

Since the promulgation of copyright some decades ago the sphere of copyright activities has broadened and became wider internationally. ${ }^{18}$ This development therefore, makes some provisions written into law quite unable to copy with situations copyright practice by modern technology. ${ }^{19}$ The administration of copyright sometimes in 1988 and 1998 attained a commendable outlook in Nigeria. This is primarily attributable to the numerous activities of the Nigerian copyright commission, a governmental organ, with corperate personality for the administration of copyright law in Nigeria. ${ }^{20}$ The administration of copyright under the repealed copyright decree of 1970 was unorganized. This was because the federal ministry of trade, on whom this responsibility was attached, failed to constitute competent authority within which to administer copyright. ${ }^{21}$

\footnotetext{
${ }^{5}$ Section 34(1) C.A. as amended CAP C28 LFN, 2004

${ }^{6}$ Section 39(1) of he Act CAP 68 LFN, 1990

${ }^{7}$ The common law copyright was abolished under the 1911 English copyright Act

${ }^{8}$ T.O. Elias "Nigerian Press Law" (1967) P.58

${ }^{9}$ S.S. Sylvester and H.J, Nwabueze (Ed) "Intellectual property laws and practice in Nigeria" Jos (2007) P.33 published mon expression Ltd Jos First edition.

${ }^{10}$ Ibid P.33

${ }^{11}$ Section 10 and 11 of CAP p.28 LFN, 2004 (hereinafter referred to as the Act)

${ }^{12}$ Section 1(1) (a-b) of the Act

${ }^{13}$ Section $6,7,8$ and 9 of the Act

${ }^{14}$ O. Ocheme, "The Law and practice of copyright in Nigeria" (2000) published in A.B.U Press Ltd Zaria second edition

15 J.O. Asin and E.S. Nwanche, "A decade of copyright law in Nigeria" published in Nigeria by the Nigerian copyright edition first edition
${ }^{16}$ Ibid

${ }^{17}$ See second schedule to the copyright Act 1989

${ }^{18}$ Copyright No.61 of 24 December, 1970

${ }^{19}$ D. Awodoye "copyright Administration in Nigeria" a need for an effective infrastructure (1992)P.139

${ }^{20}$ Section 30 of the Act

${ }^{21}$ Opcit p. 121
} 
Until the Nigerian copyright commission was reorganized as a body charged with the responsibility of overseeing collective administration, enforcement, enlightenment and development of copyright in Nigeria. ${ }^{22}$ Furthermore, it is also of significant to examine the role play by the Nigerian copyright commission and the law enforcement agencies who in reality are the foremost agents in enforcement and protection of the copyright work. $^{23}$

There is also need to highlight on the development of the protection of copyright under some international conventions.

\section{The Role Play By The Nigerian Copyright Commission}

The Nigerian copyright council is the main statutory body charge with the administration of all copyright matters throughout, the country. The council was established under the act as a cooperate body to administer the regulating conditions of the conclusion of bilateral and multilateral agreement between Nigeria and other countries, and also maintaining an effective data base on authors and their work. ${ }^{24}$ The Nigerian copyright council was re-designed to the status of the commission sometimes in April, 1996 and charged with the following responsibilities;

1. The certification of countries that are parties to treaty obligations for the purpose of determining whether a copyright work may enjoy copyright by virtue of such international obligations and such a certificate is a conclusive proof of the evidence. ${ }^{25}$

2. The regulation of the conditions for the exercise of the right of an author of graphic works.

3. The issuance of exemption certificate for the purpose of enabling to commence an action for the infringement of copyright. ${ }^{26}$

4. The commission is responsible to received and disbursement funds among approved societies from the imposition of compulsory levy on any materials used or being use to infringe copyright work. ${ }^{27}$

5. The commission is responsible for the granting compulsory licenses in accordance with the act. ${ }^{28}$

6. The commission is also responsible for carrying out of such directives of a general public or special character with respect to its functions among others. ${ }^{29}$

The commission is a body corporate with perpetual succession and a common seal any may sue and be used in its corporate name. ${ }^{30}$

\section{The Membership Of The Commission}

Pursuant to the provisions of the act, a Governing board is established by the copyright law, ${ }^{31}$ and is referred to as the "Board" which comprises of the following:

(a) A chairman, who shall be a person knowledgeable in field of copyright administration appointed by the president of the Federal republic of Nigeria. ${ }^{32}$

(b) The director general of the commission, who is also the chief executive of the commission

(c) One representative of the Federal ministry of Justice

(d) One representative of the federal Ministry of Education

(e) One representative of the Nigeria police force not below the rank of a commissioner.

(f) One representative of the Nigerian custom services, not below the rank of comptroller of custom.

Six other persons appointed by the minister representing the following authors; literary works, artistic works, musical works, cinematograph films, sound recordings and broad cast. The rationale behind such a widespread of membership across many fields is to put the future of copyright in Nigeria in the possession of the proprietary owners and public servants whose official functions relate ${ }^{33}$ to law, public policy and administration copyright.

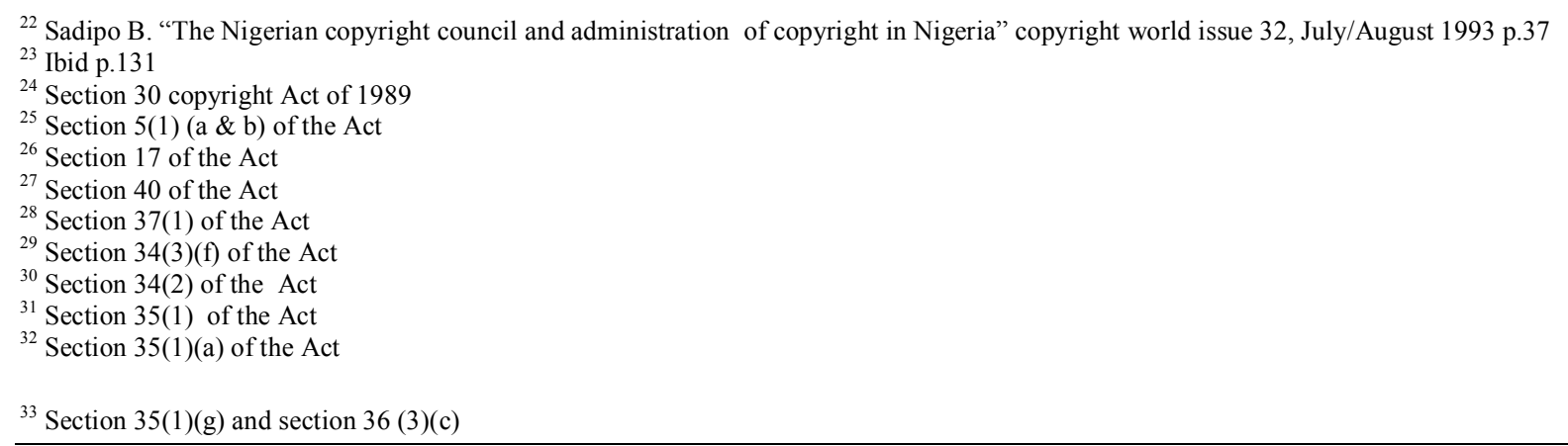




\section{The Functions Of The Nigerian Copyright Commission}

It is a well established law under the act that, the Nigerian copyright commission is charged with the following statutory duties these includes:-

1. To be responsible for all matters affecting copyright in relation to international conventions and advice government accordingly.

2. To monitor and supervise Nigerians position in relation to international conventions and advice government accordingly.

3. To enlighten create awareness and inform the public on matters relating to copyright.

4. To advice and regulate conditions for the conclusion of bilateral and multi-lateral agreements between Nigerian and any other country on copyright matters.

5. To maintain an effective date bank on authors and their works. ${ }^{34}$

6. The commission be responsible for such other matters relating to copyright in Nigeria as the minister may from time to time direct.

Apart from the responsibilities above as contained in the act, the commission also fish out some additional functions which is to be added within the limits of the commission, to include the following:-

(a). To grant compulsory licenses in accordance with the provisions of the fourth schedule to the act as well as the establishment and regulation of the copyright licenses panel. ${ }^{35}$

(b) To appoint copyright inspectors as it may deem fit in order to monitor the affairs of the commission as required by the act.

(c) Responsibility for the certification of countries that are parties to treaty and obligations for the purpose of determining whether a copyright work may enjoy copyright by virtue of such international obligations, and certification of such a kind is a conclusive proof. ${ }^{36}$

(d) Regulation and conditions which are necessary for the operation of a business involving production, public exhibition, hiring and rental of any work in which copyright subsists as provided by the act. ${ }^{37}$

(e) The approval and regulation of collecting societies for the purpose of copyright act. ${ }^{38}$

It is pertinent to submit that, there are also restrictions on execution against the property of copyright commission by any individual, organization or by the government while performing it functions. ${ }^{39}$ That's why the copyright remains as a body corporate with the statutory power to sue only and defend an action in its name. the above role is usually play by the copyright inspector which is empowered by the statutes to prosecute, conduct or defend before any court of law, any charge, investigation or complaint or other proceeding arising under the act. ${ }^{40}$ As law officer, it is an offence under the act of obstruct a copyright inspector in performance of his duties ${ }^{41}$

\section{Application Of International Treaties And Conventions}

Also, as regard to the copyright protection and administration, statutorily Nigeria was party to some international convention which include, BERNE CONVENTION, the Berne convention exist in other to protect the rights of authors in their literary and artistic work. The protection also covers musical works cinematography films and audio works. The convention further stated that, each member state must follow the principle of national treatment and imposes minimum standards on its members in that the right of registration and the right to authorize reproduction of a protection work is subject to the laid down requirement of the convention. ROME CONVENTION; the requirement of Rome convention is that each member state applies national treatment in respect of the rights which it accords to performers, record producers and broadcasting organization. ${ }^{42}$ WIPO COPYRIGHT TREATY; Nigerian being a party to the treaty most statutorily adopt an on-line digital services to the owners of the copyright works. Finally, TRIPS; otherwise known as the trade related aspected of intellectual property rights, provides that all members must comply with the substantive articles of the Berne convention, other than provisions of moral rights. ${ }^{43}$ However, the TRIPS makes generally the Berne principle confining the extent of exceptions in national legislation to the reproduction right. ${ }^{4}$

\footnotetext{
${ }^{34}$ Section 34(3)(e) of the Act

${ }^{35}$ Ibid Section 37 of the Act

${ }^{36}$ Section 5 of the Act

${ }^{37}$ Section $45(4)$ of the Act

${ }^{38}$ Section 39 of the Act

${ }^{39}$ Section 41 of the Act

${ }^{40}$ Section $38(1)(2)(3)$ and (5) of the Act

${ }^{41}$ Section 38(4) of the Act

${ }^{42}$ Article 1,2 and 3 of the Rome Convention

${ }^{43}$ Article 1-21 of the Berne Convention

${ }^{44}$ Article 13 of the Trips
} 


\section{The Nigerian Police Force; The Role Play And Its Function In Copyright And Related Matters}

The efficiency of the Nigerian police as a case study therefore is generally considered as one of the major limitation of the copyright in Nigeria. In the word of R.C. fuller and R.R. Myers, the police is a formal control agent who has been assigned the duty of consciously enforcing deliberately formulated criminal laws; and that his enforcement activity involves clear out events such as an arrest which stand out from the daily routine of life. ${ }^{45}$ The Nigerian police force is the only body constitutionally empowered to ensure the security of lives and property in Nigeria. It derives its existence from section $214(a)^{46}$ of the 1999 constitution which expressly provides that;

"There shall be a Police Force for Nigerian, which shall be known as the Nigerian police force and subject to the provisions of this section, no other police force shall be established for the federation or any part thereof'

Whereas the section 4 of the police acts, 2004 further outlines the general duties of the police as follows;

"the police shall be employed for the prevention and detection of crimes and the apprehension of offenders, the preservation of law and order, the protection of lives and properties, and the due enforcement of all laws and regulations with which they are directly charged and shall perform such military duties within and outside Nigeria as may be required of the by or under the authority of this or any other acts. ${ }^{47}$

In the same vein, the police being appointed members of the council retain their traditional power under the law to prevent and detect copyright related offences and apprehend offended as stated above. The police force remains the only reliable instrument for the enforcement of copyright offences as there is no comfortable framework for the provision of the instrument for the enhancement of inspectors work in Nigeria. Also, through the collaborative strategies of the copyright commission, the Nigerian police force is expected to play a vital role in curbing the activities of pirates and other related copyright matters as a measure towards improving the enforcement of copyright law. The Nigerian police head quarters has developed training modules designed to educate the corps on their responsibilities in copyright and related matters. ${ }^{48}$

Furthermore, with respect to the function of the Nigerian police force in copyright administration, it has been observed that the powers of the Nigerian police force, have not yet matched with action in practice of copyright enforcement throughout the country. Though, the policeman has the power and duty in law to arrest anyone who commits an offence in his presence on copyright infringement. Many copyright infringements has been committed in view more particularly in the presence of many policemen who have failed to challenge or take action, let alone arrest infringers. It has daily phenomena nowadays that the police have watched illegal photo-copying of books or dubbing of video films in its all ramification without making an arrest. ${ }^{49}$ In this present general in Nigeria it has further observed that young people hawk pirated musical cassettes singing loud illegally reproduced music of both national and international artistes, sometimes to the pleasure of the policeman who may even purchase these pirated copies displayed. It is also no secret whatsoever that pirated text books are displayed in the open and in bookshops, some of them jingle bells in calling buyers. These are all criminal acts offending the provisions of the copyright law but which have not been noticed by the police in Nigeria, but it theoretical perspective its among their duties.

The law empowers the Nigerian police force as to their functions to include:

1. Duty of a police to arrest any person who he reasonably believes to have committed a copyright infringement as provided by copyright act.

2. To enter, investigate and examine any building or factory which he reasonably suspects is being used for any activity with a infringement of copyright

3. To prosecute an offender of a copyright infringement to the appropriate court of law that have jurisdiction (Federal High Court)

4. It is also their primary task to ensure that piracy crime is maintained at tolerable level, because this is the pass mark that every police organization fights to attain.

It has been submitted that, the Nigerian police force has a vital role to play in copyright administration and other related matters, but the law has put in place some directions. There shall be the right organizational, economic and social atmosphere to enable them undertake this loudable assignment to the desired standard. ${ }^{50}$

Although, the copyright is an incorporeal right that may only be realized through legal action. Therefore the option of litigation in any particular instance would depend on the prevailing circumstances of

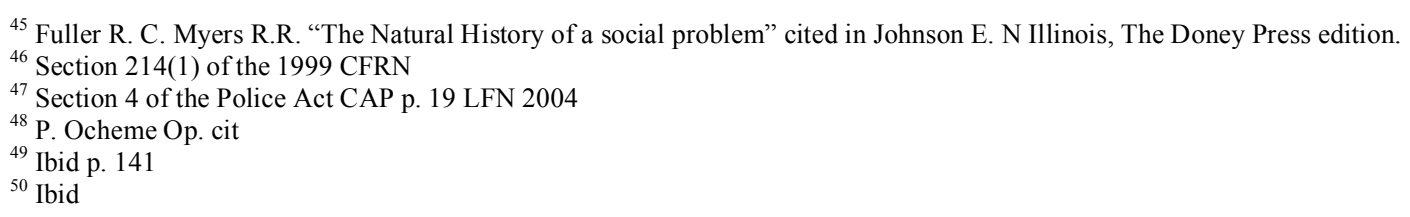


each case. In respect of which court has jurisdiction to entertained copyright and related matters, the provision of the act centers on the federal high court exclusive jurisdiction for the trial of offence or dispute under the copyright act. ${ }^{51}$ this provision of the law has again been fortified by the provision of the constitution. ${ }^{52}$ Despite, the constitutional provisional provision which does not only reinforces the position of the act rather than to settle the abnormalities that had visited the provisions in the old federal revenue court act and 1979 constitution. That section provides,

Sub section (i) "notwithstanding anything with contrary contained in this

constitution and in addition to such other jurisdiction as may be conferred upon it by an act of the national assembly, the federal high court shall have and exercise jurisdiction to the exclusion of any other court in civil cases and matters". 53

Sub section (f) " any federal enactment relating to copyright, patent,

Designs, trademarks and passing off, industrial designs and merchandise, marks, business names, commercial and industrial monopolies, combines and trusts, standards of goods and commodities and industries standards".

Infact, the court is also empowered to exercise jurisdiction in respect of criminal cases and matters pertaining to the above provisions. ${ }^{54}$ In exercising its jurisdiction, the court shall have all the powers of the state high court of justice. ${ }^{55}$ Therefore, the act further provides that in relation to the infringement of copyright which is actionable at the suit of the owner, assignee or an exclusive licensee of the copyright, as the case may be in the federal high court exercising jurisdiction in the place where the infringement occurred i.e where the defendant resides. ${ }^{56}$ Due to the above reason one can submit that the federal high court relies not only on the sensitive law but also on the adjectival laws in the course of its adjudication. It is intended also that in the event of an infringement of copyright anywhere in Nigeria, there shall be applicable rule under which the action may begin. The federal high court employs civil procedure rules in all its civil action. ${ }^{57}$ While for all criminal actions it has to make recourse to the criminal producer Act. ${ }^{58}$ And the criminal procedure code ${ }^{59}$ though a federal enactment but not applicable in the Federal High Court.

By virtue of the fact that Nigeria is a party to the international copyright convention, foreign nationals and companies operating in such member states have themselves become subject to the jurisdiction of the Federal high Court. As a result they can sue and be sued for copyright infringement committed anywhere in Nigeria. And must be in accordance with Nigeria's extradition treaties with other nations, such foreigners and their workers has became liable to Nigerian laws as Nigerians are treated under the international laws. ${ }^{60}$

\section{Conclusion}

The remarkable achievement of the copy right administration in Nigeria is the apparent realization by Nigerian state to safeguard, protect and promote creative industry and the interest of those imbued with creative talents that is exhibited in the form of commercial work to reap the benefit of their creativity. This will therefore translate into human capital development and socio economic progress; further more institutionalizing a machinery that is fighting piracy is another outstanding achievement towards enhancing the nations (GDP).

However, more needs to be done in the areas of man power and capacity building, Inter-departmental synergy most especially in fighting piracy which required multi sectoral approach toward effective and efficient copyright legal regime. The powers of the commission to design, develop and initiate guidelines and regulation towards sustainable copyright regime should be enhance to curtail excessive powers and interference by the minister. The commission should also adopt a mechanism for public engagement through effective enlightenment and massive media education. Apparently the commission needs more international engagement as a means of experience and information sharing or exchange and development. This is very important having regard to sophistication and complexity of modern digital technology era.

\footnotetext{
${ }^{51}$ Section 46 of the Act

${ }^{52}$ Section 251(1) (e) of the 1999 CFRN

${ }^{53}$ The connecting words "arising from" which featured in the equivalent provision of 1999 constitution of the federal Republic of Nigeria but the court are expected to read this omission in the provisions.

${ }^{54}$ Section 251(3) of the 1999 constitution of the Federal Republic of Nigeria

${ }^{55}$ Section 252 the chief judge of the Federal High Court is empowered under section 254 of the Constitution of the Federal Republic of

Nigeria 1999 to make rules for regulating the practice and procedure of the Act.

${ }^{56}$ Section 16 of the Act

${ }_{58}^{57}$ Order 1 and 2 Rule 8 Federal High court (civil procedure rule) as amended 2009

${ }^{58}$ CAP 80 Laws of the Federation 1990

${ }^{59}$ By virtue of Decree No.12 of the 1984 the criminal procedure code is made applicable to the FCT.

${ }^{60}$ Ibid Article 13 of trips
} 